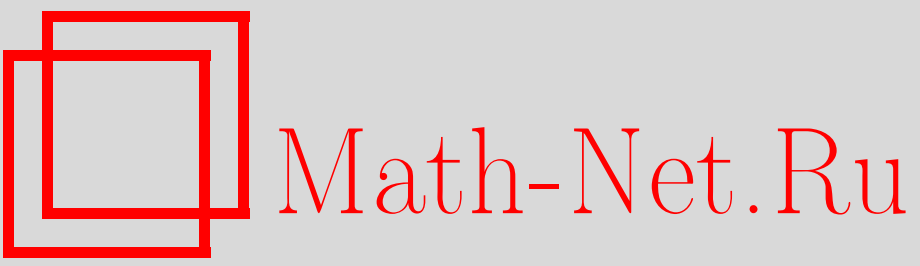

И. Н. Коваленко, О жизни и трудах Бориса Владимировича Гнеденко, Теория вероятн. и ее примен., 2013, том 58, выпуск 1, 7-26

DOI: https://doi.org/10.4213/tvp4491

Использование Общероссийского математического портала Math-Net.Ru подразумевает, что вы прочитали и согласны с пользовательским соглашением

http://www.mathnet.ru/rus/agreement

Параметры загрузки :

IP : 54.196 .121 .252

26 апреля 2023 г., 13:46:31 


\section{О ЖИЗНИ И ТРУДАХ БОРИСА ВЛАДИМИРОВИЧА ГНЕДЕНКО}

Источники очерка. Мне посчастливилось быть учеником Бориса Владимировича. Для полноты скажу, что впервые я увидел и услышал его во время его лекции для школьников на олимпиадном кружке при мехмате Киевского университета им. Т.Г. Шевченко. Потом для нас, студентов 3-го курса мехмата, Б. В. - так мы его называли - читал курс теории вероятностей.

Один из университетских преподавателей ежегодно прослушивал этот курс и удивлялся, что Б. В. излагал материал всякий раз по-новому!

В то время уже был доступен созданный им «Курс теории вероятностей», изданный вначале на украинском языке [1] (Б. В. всю жизнь оттачивал свой учебник и переиздавал его на русском и многих других языках; см. [2]).

После второго курса произошло разделение студентов на математиков и механиков. Записавшись к математикам, я был прикреплен к кафедре теории вероятностей, руководителем которой в то время был Б. В.

В 1957 г., когда я окончил университет, Б. В. взял меня в аспирантуру при Институте математики АН УССР. Под руководством Б.В. была написана моя кандидатская диссертация, защищенная в 1960 г.

В этом же году Б. В. переехал в Москву, в знаменитый МГУ - Московский государственный университет им. М. В. Ломоносова. Вначале он был профессором, а потом - до самой своей кончины - заведующим кафедрой теории вероятностей мехмата МГУ. В поисках новых задач я обратился к известному ученому Н. П. Бусленко, заместителю по науке начальника оборонного института, и Николай Пантелеймонович предложил мне должность старшего научного сотрудника этого института; мне с семьей была предоставлена квартира. Московское десятилетие (январь 1962 г. — июнь 1971 г.) было для меня богато событиями: я вернулся в Киев уже доктором технических наук (1964), доктором физикоматематических наук (1970), профессором (1965). Однако одним из наиболее ярких воспоминаний об этом десятилетии навсегда останется соруководство (вместе с А.Д. Соловьевым и Ю.К. Беляевым) семинаром

${ }^{*}$ Институт киберентики им. В. И. Глушкова НАН Украины, Киев, Украина; е-mail: kovigo@yandex.ru 
по теории массового обслуживания и теории надежности, главным руководителем которого был Б. В. Этот семинар фактически был научной школой: по оценке Б. В., не менее 20 участников семинара стали докторами наук.

Незадолго до моего возвращения в Киев сотрудникам военных институтов было запрещено посещать семинары, где участвовали иностранцы, а в гнеденковском семинаре их всегда было очень много: как заметил В.М. Золотарев во вступительной статье к учебнику [2], «Б. В. Гнеденко - основатель вероятностных школ на Украине и в Германской Демократической Республике». Впрочем, и помимо семинара для нас, его учеников, всегда был открыт гостеприимный дом Бориса Владимировича и Наталии Константиновны. Кроме математики, мы могли получать там советы по любым вопросам и проблемам. Таким образом, тесное общение с Б. В. у меня, как и у многих других его учеников, продолжалось вплоть до распада СССР.

Другим источником информации для этого очерка послужили работы Б. В. (в основном книги), расположенные в списке литературы в порядке цитирования.

Третьим источником послужили воспоминания учеников и соратников Б. В. - [3], [4] и, наконец, воспоминания самого Бориса Владимировича [5] - настоящий шедевр такого жанра литературы. Большое и благородное дело осуществляет Дмитрий Борисович Гнеденко, собирая и готовя для печати работы Б. В., в том числе и «Воспоминания».

Ранние работы Б. В. Гнеденко. Борис Владимирович Гнеденко родился 1 января (н. с.) 1912 г. в Симбирске. Его отец Владимир Васильевич Гнеденко был землеустроителем, а дед и бабушка - крестьянами Полтавской губернии, переселившимися в Казанскую губернию России в 70-х гг. XIX столетия. Б. В. закончил Саратовский университет в 1930 г.

По предложению Г.П.Боева, переехавшего в Иваново для работы в Текстильном институте, Б.В. последовал за ним и работал там до 1934 г., совмещая педагогическую деятельность с научной. Здесь впервые проявился большой талант Б. В. к изучению математических моделей реальных процессов.

Функционирование прядильного цеха состояло в том, что оператор следил за работой порученного ему станка; если станок останавливался из-за обрыва нити, оператор связывал нить и вновь запускал станок. В то время в текстильной промышленности внедрялось так называемое многостаночное обслуживание, когда одному оператору стали поручать несколько станков. Для выбора оптимальной схемы многостаночного обслуживания нужно было решить соответствующую вероятностную задачу, что и сделал Б. В. [6]-[8].

На мехмате МГУ. В апреле 1934 г. Б. В. приступил к двухмесячной стажировке в МГУ, где сразу влился в этот выдающийся коллектив. 
Б. В. пишет в [5]: «Механико-математический факультет очаровал меня широтой математических идей, преданностью науке, стремлением помочь молодежи овладеть прочессом творчества».

А.Н.Колмогоров и А.Я. Хинчин заметили большой талант Б.В.; Хинчин обещал взять его в аспирантуру. Осенью 1934 г. Б. В. блестяще сдал экзамены и был зачислен в аспирантуру.

Вместе с А.Н. Колмогоровым и А. Я. Хинчиным Борис Владимирович интенсивно занимался теорией суммирования независимых бесконечно малых случайных величин, в особенности классом предельных распределений, условиями сходимости.

Приведем один результат Б. В. ввиду простоты его формулировки. А.Я.Хинчин выдвинул гипотезу, что характеристическая функция определяется однозначно при всех $t,-\infty<t<\infty$, если известны ее значения при $-a<t<a$. Б. В. опроверг эту гипотезу.

Трагическое событие и возвращение к жизни. В конце 1937 г. Б. В. был арестован по ложному доносу неких лиц, бывших с ним в туристском походе. Следователь добивался от Б. В. признания в контрреволюционной деятельности, а главное, в том, что А.Н. Колмогоров якобы возглавляет контрреволюционную организацию. Б. В. мужественно перенес все мучения и издевательства (один допрос продолжался восемь суток без перерыва) и не подписал того, чего от него пытались добиться. В тюрьме его продержали полгода и выпустили, когда репрессии пошли на спад. Его восстановили на работе в МГУ, в чем главную роль сыграл А.Н. Колмогоров, сотрудники же окружили его сочувствием и вниманием. К началу войны Б. В. уже защитил докторскую диссертацию, состоявшую из двух частей: теории суммирования независимых случайных величин и теории максимального члена вариационного ряда. Кстати, Б. В. открыл в качестве возможного предельного закона для максимального члена вариационного ряда закон, называемый в западной литературе законом Вейбулла, хотя следовало бы ГнеденкоВейбулла. Оппонентами по диссертации выступили виднейшие математики С. Н. Бернштейн, А.Н. Колмогоров и А.Я. Хинчин. К этому времени Б. В. уже был женат на Наталии Константиновне Добровольской (после свадьбы - Гнеденко). Они жили в добре и согласии в течение 47 лет, пока эта исключительно рассудительная и добрая женщина была жива.

Работа в эвакуации. Когда немцы подошли к Москве, началась эвакуация; в частности, сотрудники МГУ, не взятые немедленно в армию, были эвакуированы с семьями в Ашхабад, где им были созданы довольно сносные условия жизни и где они встретили радушный прием местного населения. Однако московские ученые были весьма обеспокоены тем, что их только спасают и не дают возможности применить свои знания к решению оборонных задач. В едином порыве они обратились 
с просьбой переселить их в город, где было бы много объектов оборонной промышленности; таким образом, новым городом эвакуации Б.В. и многих других работников МГУ стал Свердловск. Здесь его талант прикладника, а не только теоретика, нашел свое блестящее применение. Приведу яркий пример из его воспоминаний [5, с. 171-172].

«Беседа с Б. П. Орловым приблизила меня $к$ пониманию всей сложности обстановки на фронтах и подтолкнула $\kappa$ тому, чтобы как можно скорее найти необходимое дело, которое я могу сделать лучше, благодаря моим знаниям и умениям, чем подавляющее большинство моих сограждан.

Первое дело не заставило себя долго ждать. В университете меня разыскал Н. А. Бородачев, которого я знал еще по Москве. Он работал в Институте машиноведения и занимался вопросами точности механизмов, был связан с промьишенностью, в частности с приборостроительной, и вхож на заводы. Он предложил мне посетить для начала один приборостроительный завод, где изготовлялись причельные приспособления для авиачии и артиллерии. Через три дня мы уже были на заводе. Картина, которую я увидел, была мне известна по рассказам, но когда я ее увидел воочию, то она буквально перевернула всю мою душу.

В чехах работали почти только женщинь, старики и дети в возрасте от 12-13 до 16 лет. Многие еще не вылли ростом, итобы стоять у станка, им подставляли ящики. Мальчики и девочки, которым по возрасту полагалось бегать, играть, учиться, челую смену простаивали за станками и делали крайне необходимую для фронта продукиию.

В иехе я заметил кучи деталей, о которых мне было сказано, ито это бракованные изделия. Сопровождавший меня инженер добавил, что если бы бракованные детали можно было превратить в действующие изделия, то это позволило бы выполнить полугодовой план и снабдить войска необходимьми приборами в достаточном количестве. Эта проблема меня живо заинтересовала.

Перед уходом я задал лишь два вопроса: 1) могу ли я получить схему прибора и 2) должен ли этот прибор быть восстанавливаемьлм или же это можно не учитьвать?

Ответьи я получил немедленно: схему я должен изучить на заводе, а от прибора не требуется восстанавливаемости.

Я попросил разрешения посещать завод примерно в течение недели и производить чисто статистическую работу: измерение основньих параметров деталей. Разрешение было тут же получено, и через четверть часа мне выцали временный пропуск.

Я тищательно изучил рабочие чертежи, допуски и сопряжение деталей. Схема прибора была очень простой: геометрически она пред- 
ставляла собой последовательность объемлемьх и объемлющих деталей. Затем я познакомился с частью бракованных изделий. Оказалось, что брак, главньм образом, связан с большим разбросом размеров. Неделю я производил замерь деталей и, в конче кониов, разбил их (каждое множество однотипных деталей) на семь групп по размерам, которье я пронумеровал от 1 до 7. После этого стал изучать взаимодействие частей различных размеров. У меня получилось, что из деталей одного номера можно собирать действующие приборьл. По моим указаниям была собрана пробная партия. Далее начались испьтания, показавшие, что приборьл, собраннье из деталей с номерами от 2 до 6, вполне пригодньи и дают необходимую точность. Приборь же, собраннье из деталей с номерами 1 или 7, нестабильнь в работе. Я прикинул, что примерно $90 \%$ нестандартных деталей можно превратить в действующие приборы.

Куча брака быстро таяла, а выпуск приборов резко возрос. Моральное удовлетворение от сделанного било исключительно велико. Я помог стране дать фронту нужное ему оружие. Моральное удовлетворение было связано и с тем, что я понял, как важна идея, которая руководит мьслями и действиями человека».

Львовский период (1945-1949). В конце 1944 г. Николай Николаевич Боголюбов сообщил Б. В., что в скором времени Академия наук УССР объявит выборы своих членов, и предложил ему баллотироваться на вакансию члена-корреспондента. Посоветовавшись со своими учителями и друзьями А.Н. Колмогоровым и А.Я. Хинчиным, Б.В. получил от них одобрение этой идеи и подал документы в Президиум АН УССР. В феврале 1945 г. выборы состоялись; Б. В. получил извещение о своем избрании. Закончив учебный год в МГУ, Б.В. поехал в Киев улаживать дела. Его сопровождали Наталия Константиновна и маленький сын Дима (р. 1943).

Президиум АН УССР принял решение направить Б. В. на работу во Львов «для восстановления работы учреждений Академии и Львовского университета». Должности, предложенные ему, - руководитель Отделения математики Академии наук и профессор-совместитель Львовского университета. Кроме преподавания на него возлагалась обязанность подбора научно-педагогических кадров.

В то время во Львове еще работало много польских математиков, в том числе ученые мировой известности С. Банах и С. Мазур; впрочем, Банах умер 31 августа 1945 г.; слова Б. В. о нем: «Уиел из жизни не просто вылаюшийся математик, львовская математика потеряла свою $\partial y u y \gg$.

Поляки в массовом порядке уезжали в Польшу, и Б. В. пришлось находить математиков в пределах Союза. В частности, во Львов переехал видный ученый в области дифференциальных уравнений Ярослав Бо- 
рисович Лопатинский (позднее академик АН УССР). Из вероятностников, бывших учениками Б. В., надо упомянуть Е. Л. Ющенко (Рвачеву), Е. К. Лебединцеву, И. Д. Квита.

Моя мать жила во Львове многие годы, начиная с 1939 г. (за вычетом военных лет). Я фактически ежегодно приезжал к ней, как правило с женой и дочерьми. Во время этих визитов работал в замечательной Научной библиотеке, подружился с И. Д. Квитом. Иван Дмитриевич восторженно вспоминал о Б. В., говорил, что во Львове все любили и уважали Бориса Владимировича.

Уже было упомянуто об учебнике [2], принесшем мировую славу его автору. Над этой книгой Б. В. работал именно во Львове (написана она была на русском языке, перевод на украинский осуществлен Е. Л. Ющенко и Е. К. Лебединцевой). Во Львове была написана и всемирно известная монография [9]. Основной текст был написан Б. В., затем А. Н. Колмогоров добавил некоторые параграфы и сам сдал рукопись в печать как книгу обоих авторов. (Сам Б. В. заметил, что любое вмешательство А.Н. Колмогорова будет полезно для книги.)

Киевский период (1949-1960). В 1948 г. Б. В. был избран академиком АН УССР. В 1949 г. Президиум АН УССР принял решение перевести его на работу в Киев. Борису Владимировичу было предложено возглавить отдел теории вероятностей Института математики АН УССР и параллельно кафедру теории вероятностей и алгебры на мехмате Киевского университета им. Т. Г. Шевченко. В январе 1950 г. совершился переезд в Киев Б.В.Гнеденко и его семьи (к ней прибавился младший сын Александр - Алик). Как в Академии, так и в Университете Б. В. нашел в качестве сотрудников талантливых, перспективных математиков: Л. А.Калужнина после его переезда в Киев из Германии, М. И. Ядренко, И. И. Гихмана, Е.Л. Ющенко (их уже нет в живых), В. С. Королюка; позже к ним присоединились А. В. Скороход, В. С. Михалевич. На киевское десятилетие выпал ряд зарубежных поездок Б. В.: самая продолжительная в ГДР, в Чехословакию (из ГДР), Румынию, США. В ГДР благодаря педагогической и научной деятельности Б.В. сформировалась научная школа: его учениками были Г.И. Россберг, П.Франкен, Д. Кёниг, У.Арндт, Ф.Шмидт (книгу Франкена с соавторами [10] я перевел на русский язык).

В течение двух лет (1952-1954), по договоренности с А. Н. Колмогоровым, аспиранты Бориса Владимировича - В. С. Михалевич, В. С. Королюк и А.В. Скороход проходили аспирантскую подготовку в Москве: первые двое у А.Н. Колмогорова, последний у Е. Б. Дынкина. Вернулись они в Киев, преисполненные интересных идей и задач, которыми искренне делились с более молодыми математиками. Я этим удачно воспользовался, написав в 1957 г. дипломную работу под руководством В. С. Михалевича, а в 1960 г., когда Б. В. уехал в Москву, он передал от- 
дел В. С. Королюку, бескорыстно помогавшему мне, как и другим аспирантам. Оба они, ставя передо мной задачи, говорили, что эти задачи от Колмогорова; это придавало мне энтузиазма.

А.Н.Колмогоров приглашал и меня в МГУ, но пришлось отказаться: моя жена Лена была в положении (родила дочь Галину в апреле 1959 г.) и было не до московской аспирантуры. А. Н. Колмогоров, впрочем, предоставил мне возможность командировок к нему (по его вычурному выражению, «с правом разговаривать»). Всего состоялось несколько командировок, но очень важных для меня, особенно благодаря критике со стороны Андрея Николаевича.

Несмотря на поездки, всевозможные административные нагрузки, обязанности в Президиуме и на кафедре, Б. В. успел в течение киевского десятилетия много сделать в математике, теоретической и прикладной.

Б.В. с соавторами принадлежит большой труд по написанию книги [11], не только ставшей одной из первых в СССР по программированию, но также воплотившей новые идеи адресного программирования.

Б. В. очень увлекся созданием электронного диагноста - устройства для автоматического установления диагноза о характере сердечного заболевания человека. Верными помощниками Б.В. в этом деле были Е.А. Шкабара, Л. Н. Дашевский, М. А. Куликов.

Б. В. стал директором Института математики в 1955 г. Он добился перевода лаборатории академика С. А. Лебедева - создателя первой в континентальной Европе ЭВМ «МЭСМ» - в Институт математики после отъезда Лебедева в Москву. Среди идей, восходящих к Б. В., была идея создания в Киеве Института кибернетики, конструирования ЭВМ для решения систем линейных уравнений с числом переменных до 700 .

Мне наиболее близко то, над чем работал отдел теории вероятностей Института математики под руководством Бориса Владимировича и затем В. С. Королюка.

В.С.Королюк с аспирантом Д.В.Гусаком вел тему, связанную с факторизационными тождествами. Д.В.Гусак стал впоследствии видным ученым, доктором наук. Его творческая активность длится более 50 лет.

Б.В. вел две темы: задачи теории надежности и системы обслуживания с нетерпеливыми требованиями (queueing with impatient customers).

У Б. В. возник интерес к надежности сложных систем - вследствие ознакомления с рядом прикладных задач (из теории резервирования) и недавним на то время результатом Б. А. Севастьянова, состоящим в том, что формулы Эрланга, выведенные еще в 1908 г., справедливы не только в случае экспоненциального распределения длительности разговора, но и для общего распределения. Б. В. рекомендовал нам воспользоваться 
методом Б. А. Севастьянова для вычисления коэффициента готовности ряда схем резервирования. Успеха добились Т. П. Марьянович (впоследствии член-корреспондент АН УССР) и Т.И. Насирова (теперь доктор наук, работает в Баку). Однако в некоторых случаях метод не срабатывал - почему? Мне удалось раскрыть секрет, найдя «критерий инвариантности (нечувствительности)», сыгравший определенную роль в создании теории нечувствительности систем и сетей обслуживания. Французский профессор Робер Фортэ (Fortet), посетивший Б. В. в Киеве в 1960 г., пригласил меня с докладом на Конгресс по телетрафику в Париже (1961). Хотя поехать туда мне не пришлось, доклад рассматривался там заочно и получил известность в СССР и на Западе.

Системами с нетерпеливыми требованиями занимался С. М.Броди - аспирант Б. В. Он исследовал так называемые системы с $\tau$-ожиданием и с $\tau$-пребыванием. По идее В. С. Королюка я исследовал более общую систему обслуживания, включающую эти обе в виде частных случаев. А. Н. Колмогоров одобрил эту работу.

В Киеве существовало радиотехническое военное училище КВИРТУ, где велись работы по исследованию операций под руководством профессора Н. А. Шишонка. Б. В. прочитал в этом училище курс лекций по теории массового обслуживания, стараясь, как он это блестяще умел, связать теорию с практическими задачами противовоздушной обороны. Лекции имели большой успех, и командование училища предложило издать их в виде книги в издательстве КВИРТУ. Лекции были изданы тремя выпусками (см. [12], [13]).

В июле 1960 г. Б. В. Гнеденко со своей семьей переехал в Москву. В своих воспоминаниях [5] главу об украинском периоде своей жизни и работы он заканчивает следующими словами: «Я полюбил замечательную страну Украину. И не моя вина, что я покинул этот полюбившийся мне край и очень талантливый народ».

Второй московский период (1960-1995). Много внимания Б. В. уделял организации статистического контроля и служб надежности. Организовывались консультации для инженеров в Политехническом музее, поездки по многим районам, вплоть до Дальнего Востока, семинары и конференции.

Активными сотрудниками Б.В. в этой деятельности были инженер Я.М.Сорин, прикладной статистик Я.Б.Шор, математики А. Д. Соловьев, Ю. К. Беляев, Е. В. Чепурин, И. А. Ушаков, В. А. Каштанов, В.В.Калашников и другие. Из прикладных исследований кафедры Б. В. нельзя не отметить работы Л.Г. Афанасьевой, создавшей теорию аэродрома как системы массового обслуживания. Существенный вклад в теорию и приложения управляемых процессов сделали Л. Г. Афанасьева, В. В. Рыков, Е. Ю. Барзилович, В. А. Каштанов.

В течение второго московского периода Б. В. активно занимался те- 
орией надежности сложных систем. Его излюбленный подход - метод суммы случайного числа $\nu$ независимых случайных величин $\xi_{1}, \ldots, \xi_{\nu}$. В 1964 г. Б. В. опубликовал две работы [14], [15], где с помощью случайных сумм построена теория распределения времени до отказа дублированной системы. Этот метод мастерски развил А. Д. Соловьев; многие задачи асимптотического анализа надежности решены учениками А. Д. Соловьева - Д. Б. Гнеденко и другими.

Фундаментальная книга [16] - фактически единственная в мировой литературе, где дана строгая теория вероятностных и статистических задач надежности. Она переведена в США, Японии, Германии, Польше, Румынии, Венгрии.

Б.В. интересовался распределениями случайных сумм до конца своих дней; последняя книга [17] вышла уже после его смерти. Когда я переехал из Киева в Москву, Б. В. предложил мне издать совместную монографию «Введение в теорию массового обслуживания», переделав соответствующим образом киевские «Лекции по теории массового обслуживания». Это было выполнено за три с лишним года, и в 1966 г. книга [18] вышла из печати. Вскоре книга была переведена в Иерусалиме (1968), в Берлине (1971), в Варшаве (1971). В 1987 г. осуществлено 2-е русское издание в «Науке», в 1989 г. - его английский перевод издательством Birkhäuser, Бостон. В последние годы вышло несколько изданий книги в издательстве URSS, Москва.

Большой труд был выполнен коллективом советских и немецких (ГДР) вероятностников - написание и издание справочника по теории массового обслуживания [19]. Редакторами книги были Б. В. Гнеденко и Дитер Кёниг.

Книги об истории науки. В данном разделе упоминаются книги Б. В. об истории науки, написанные в разные годы: мне кажется, что лучше собрать их вместе, чем разбрасывать по разным разделам.

«Курс теории вероятностей» [1], [2] в некоторых изданиях выходил без исторического обзора, но в последних изданиях обзор восстановлен после тщательного исследования, предпринятого Б. В. в связи с историей возникновения основных понятий теории вероятностей.

Приведу выдержку из статьи [20], изменив соответствующим образом нумерацию работ, цитируемых в ней.

«Долголетие учебника [2] объясняется, прежде всего, редким талантом автора, умевшего рассказать с предельной ясностью об основных понятиях и закономерностях стохастических экспериментов. Кроме того, Б.В. прекрасно ориентировался в истории развития основных теоретико-вероятностных понятий. Свидетельство этому - замечательный очерк истории теории вероятностей, помещенный в учебнике.

Этот очерк - проявление еще одной грани его таланта: дара 
историка. Историко-математическое наследие Б. В. велико и разнообразно. Прежде всего, это работы по истории теории вероятностей и математической статистики: о достижениях в этой области выдаюшихся ученых прошлого - К. Ф. Гаусса, Н. И. Лобачевского, М. В. Остроградского, П. Л. Чебьшёва, А. М. Ляпунова; о развитии этих наук в России и на Украине; об их истории в XIX в. Но интерес Б.В. не ограничивался исключительно историей тех разделов математики, в которых трудился как математик он сам. Его интересовали общие проблемь истории математики (см., например, написанную совместно с К. А. Рьббиковым и Н. И. Симоновым его статью [21]), развитие математических исследований в Московском университете (см. его совместную с П. С. Александровым и В.В. Степановым статью [22]), творчество крупнейших отечественных математиков (так, М. В. Остроградскому он посвятил две книги - первую он выпустил в 1952 г. [23], вторую, в соавторстве с И. Б. Погребьлским, 一 в 1963 г. [24]). Как легко видеть, любимой темой его историко-математических исследований всегда оставалась история отечественной математики. Актуальньм проблемам в этой области посвящена написанная им совместно с И. Б. Погребисским, И. З. Штокало и А. П. Юшкевичем статья [25]. Эти проблемь и их решение - сюжет многих работ Б. В., из которых выделяется небольшая по объему $(248$ с.) книга «Очерки по истории математики в России», опубликованная в 1946 г.

Эта книга выросла из реферата по истории и философии математики, который Борис Владимирович подготовил в 1934-1937 г2., будучи аспирантом механико-математического факультета МГУ. Рукопись находилась у руководителя аспирантским философским семинаром, профессора С.А.Яновской, в начале войны уехавшей в эвакуаиию в Пермь. Софья Александровна забрала рукопись с собой, сохранила ее и по возвращению в Москву вернула Борису Владимировичу. Из этой рукописи и родилась книга, которая увидела свет уже по окончании войнь. «Очерки» сыграли выдающуюся роль в развертывании в нашей стране исследований по истории отечественной математики, а также в качестве учебного пособия по курсу истории математики в университетах и педагогических институтах. До сегодняшнего дня она сохраняется в списке литературь, рекомендованной по этому курсу для студентов механико-математического факультета МГУ.

Заметим, что к моменту выхода книги в свет ее автору было всего 34 года. Обычно же к историческим исследованиям ученого влечет на «склоне» лет, когда творческий потенциал уже успешно использован. Б. В. был уверен в необходимости исторического анализа достижений отечественных математиков, понимания неразрывную 
связь развития математики в России в прошлом и настоящем независимо от сочиальных обстоятельств. А, по-видимому, реалии Великой Отечественной войны и ее завершение стали дополнительным стимулом $\kappa$ анализу сочиальных общественньх проблем.

В это же время всевозможные «дискуссии» по разнообразнылм проблемам развития науки и культурь под эгидой партии и правительства создали благоприятнье условия для объединения «преданньх идеям марксизма-ленинизма» «сознательньх» членов общества против творческой интеллигениии.

Творческая личность свободна, а потому трудно поддается управлению, а тем более раболепному бездумному подчинению главенствующей идеологии. «Очерки по истории математики в России» Бориса Владимировича бъли живительной струей объективного исторического анализа, опирающегося на достовернье факты, демонстрирующего величие научных открыттии, их вневременной характер. $K$ тому же автор книги - молодой энергичньй профессор университета, пользовавшийся заслуженным авторитетом и любовью у студентов».

Новые успехи семинара. Из [5], с. 495. Б. В. описывает работу с одной испаноязычной аспиранткой. «Она изучила классические труды Муавра, Байеса, Лапласа, просмотрела учебники по теории вероятностей XIX века. По моей просьбе она нашла автора задачи о встрече. Постепенно я понял, что диссертаиия будет сделана, по крайней мере, в части сбора материала. Я настаивал на том, чтобь она выступала на моем семинаре, рассказьвала про открытые ею исторические фактыл. Одновременно я обдумывал, как вылгрышно изложить полученный материал. Попьткка заставить ее саму написать диссертацию окончилась неудачей. Оказалось, что она не умеет излагать свои мьслли ни на одном языке (в том числе и на родном испанском). Я не в первый раз сталкивался с таким положением, что аспирант получал вполне удовлетворительнье научные результать, но когда дело доходило до их литературного изложения, то он терялся, и даже многократные переписььвания текста не приводили ни к чему хорошему. Эту часть работьл я взял на себя. Диссертация была написана в срок».

Б. В. писал, как правило, без черновика, пользуясь старой пишущей машинкой. Печатал он быстро, ударяя по клавишам только указательными пальцами обеих рук. В начале заложенного листа бумаги нередко значилась «нерусская» фамилия какого-нибудь аспиранта.

Меня переводят в Киев. Из [5], с. 255-256. «Осенью 1950 года на открытом партийном собрании факультета я внес предложение организовать Факультетский лекторий, в котором читались бьл лекиии об основных проблемах математики, ее методологии, истории, проблемах, вылвигаемьх перед математикой практикой сочиалистического строительства. Идея этого лектория была восторженно встречена 
студенчеством и частью преподавателей. Однако руководство факультета сделало все возможное, итобы погубить эту идею. В частности, секретарь партийной организачии факультета Дмитренко на комсомольском собрании требовал прекращения этой затеи, мотивируя это тем, что некому нести ответственность за идеологическое содержание лекиий. В результате состоялось всего три лекиии, а затем сама идея организачии факультетского лектория была похоронена».

60-е годы, поезд Москва-Киев. Один участник кампании против Б.В. вспоминал: «Мы его обложили со всех сторон, как волка красными флажками, и ему уже ничего не оставалось, как перебраться в Москву». Вероятно, об этом ему было приятно вспомнить.

Поездки в Красноярск и Иркутск. Из [5], с. 514-516. «Мои иркутские коллеги организовали поездку на Байкал и на Байкальскую биологическую станиию. Биостанцию, конечно, очень интересно посетить, поскольку там собрань исчерпьвающие сведения об озере и его обитателях. Озеро огромно и содержит бесконечную ченность - чистейшую пресную воду, в которой живут многочисленные виды эндемиков - рыьб, моллюсков, разного вида рачков, встречающихся только в этом бассейне.

Точнее, вода была чистой лишь до постройки челлюлознобумажного комбината. Работники биостаниии выступали против этого строительства. Но что может сделать маленькая биостаниия, когда решение о строительстве принято правительством и всесильным ЦК КПСС. Тогдашнее руководство Академией наук дало заключение, что строительство комбината не повредит озеру. $A$ в результате оказалось, что в жабрах байкальского омуля стали находить остатки измельченной древесинь, выбрасываемой со сточными водами комбината. Оказывается, очистнье сооружения недостаточно надежны и, попадая в озеро, остатки технологического проиесса живут вместе с озером: воды перемешиваются и вредные вешества разносятся по всей акватории озера и по всем его «этажам 》. Комбинат, быть может, и приносит казне прибыль, но он наносит ущерб природе края в самом чувствительном его месте - уникальном озере Байкал. Конечно, портят воды Байкала и реки, впадаюшие в озеро, но это относительно небольшое воздействие по сравнению с воздействием комбината».

В. М. Глушков. Из [5], с. 349-350. «В это время Н. И. Симонов, которого я знал еще по довоенныл временам в МГУ, защитил докторскую диссертачию по истории математики и переехал в Киев. Он мне сообщил о В. М. Глушкове - свердловском математике, с успехом закончившем докторантуру у А.Г. Куроша, - и очень рекомендовал его как увлеченного математика. Я пригласил В. М. Глушкова для пе- 
реговоров в Киев, и где-то в самом конце лета или в начале осени он появился у меня. Я его принял с распростертыли объятиями, так как мне понравились его работы по алгебре. К тому же алгебраические исследования следовало развивать и в Киеве. Современная алгебра никем у нас не била представлена».

Принципиальные разногласия Бориса Владимировича и В. М. Глушкова зашли очень далеко и послужили одной из главных причин отъезда Б. В. из Киева в Москву. В прекрасной небольшой книге [4] членкорреспондент НАН Украины Т.П. Марьянович по-человечески анализирует деятельность обоих знаменитых людей как верный ученик Б. В. и многолетний ведущий сотрудник В. М. Глушкова. Моя судьба во многом схожа с судьбой моего друга Т. П. Марьяновича: работаю в глушковском институте с июня 1971 г., избран в академики АН УССР в 1978 г.

Работа над рукописями «Предельных распределений для сумм» и «Курса теории вероятностей». Из [5], с. 227. «Я убежден также в том, что должен быть не один, а несколько учебников, написанных с различных педагогических и научных позиций. Читатель сам разберется, какой из них ближе всего подходит $\kappa$ его запросам, $\kappa$ его интересам. Я очень рад, что в настоящее время у нас имеются такие разнье учебники, как книги А. А. Боровкова, А. Н. Ширяева и моя. Известно, что все переставшее развиваться, совершенствоваться, отмирает, перестает удовлетворять общественныл потребностям, уходит в историческое прошлое. Учебная литература должна жить, а значит, совершенствоваться».

Поездка в Новую Зеландию. Из [5], с. 440. «Я был потрясен прочессом стрижки овеи. Хозяин жестом подозвал $\kappa$ себе двух собак, и они, полнье внимания, уселись у его ног. Новьм жестом хозяин послал их $\kappa$ отаре овец, пасшейся метрах в двухстах-трехстах от нас. Собаки отогнали штук десять овеи и погнали их к большому сараю, в котором те попали в лабиринт, пропускавший по одной овие $\kappa$ калитке. Около калитки мощный мужчина среднего роста хватал овиу и в течение пятидесяти двух секунд хорошо отработанньми движениями остригал ее и успевал еще за это время отделить шерсть второго сорта от основной массь первого сорта. Далее он хватал вторую овиу, третью. В таком темпе он остриг пяток овеи, затем протянул мне полотенце и попросил завязать ему глаза. С завязанньли глазами он остриг очередную овиу за пятьдесят семь секунд, правда, допустив при этом два маленьких пореза, точнее, даже иарапинь. Стрижка продолжалась, и вдруг он обратился ко мне с вопросом: «Вьи, вероятно, думаете, что я прилагаю большие бизические усилия, переворачивая овеч и удерживая их в нужном мне состоянии?» Я выразил согласие. Тогда стригаль произнес следуюшие запомнившиеся мне слова: 
- Ничего подобного, овца делает все сама, а я только нажимаю на ее нервные чентры. Вот сейчас мне нужно, чтобы овца повернулась с правого бока на левый, я нажимаю на этот иентр.

Овиа повернулась, словно по команде.

- Теперь мне нужно закрепить ее в таком положении. Я нажимаю вот на этот иентр.

И овиа застьла в полной неподвижности. Стригаль закончил стрижку, не связывая овцу, не прибегая к посторонней помощи.

$B$ этот момент мне пришла в голову мьсль: наверняка наши физиологи животных знают все об этих иентрах, но не сделали из своих знаний соответствующих практических вывводов. И люди стригут овеи по старинке, прибегая $\kappa$ помощи здоровенных мужчин, которье держат овиу за ноги и за туловище.

Назначение науки не только разыскать «нервные чентры проблемь», но и использовать эти знания для практики, для жизни. И мьи должны в университетах и других учебньх заведениях пробуждать потребность у молодежи искать такие «нервные иентры» и думать об их использовании. В этом заключается основа общественного прогресса. Молодое поколение должно приучаться искать новое и думать о совершенствовании старого».

Можно обратить внимание не только на интереснейший эпизод, но и на проникновенность Б. В.: он тут же нашел разницу между тем, что по-английски называется capability и ability - начиненностью знаниями и умением их использовать.

Сотрудничество Б. В. Гнеденко с иностранными учеными. О том, что Б. В. создал вероятностную школу в ГДР, уже упоминалось. Немецкие ученые Г.-И. Россберг, Д. Кёниг, Д. Штойян и другие многократно посещали СССР. Так, Россберг приезжал в Москву, когда он переводил на немецкий язык нашу с Б. В. книгу [13], сделав большое число существенных замечаний.

В Великобритании Б. В. тесно общался с Д. Кендаллом, о чем Кендалл с удовольствием рассказывал мне и показывал фотографии, сделанные им на совещании по теории вероятностей и математической статистике, кажется, в Тбилиси.

Из французских ученых «первой звездной величины», тесно общавшихся с Б. В., надо назвать М. Р. Фреше и Р. Фортэ.

Из виднейших американских ученых назову Н. Винера и Джерси Неймана. Помню такой эпизод. В конце 50-х годов Нейман запланировал поездку в Киев. Узнав, что Б. В. уезжает в Москву, он сказал: «Зачем же мне ехать в Киев?»

В Польше Б. В. знал фактически всех видных математиков. Большая дружба связывала его с Э. Фиделисом. 
Б. В. общался со знаменитым индийским статистиком Рао. (Мои товарищи и я видели его на Третьем съезде математиков СССР в 1956 г.)

Длительное общение связывало Б. В. с новозеландским математиком Д. Вир-Джоунзом (Vere-Jones). (Я познакомился с ним в доме Б. В. в 60-е годы.)

В Израиле и путем переписки Б. В. общался со многими эмигрантами из СССР.

Выиграв грант Фонда Дозора, я работал в 1999 г. в Университете им. Бен-Гуриона на кафедре проф. И. Б. Герцбаха, хорошо знакомого с Б. В. по работам в области теории надежности.

А. Дворецкий сделал первый перевод нашей книги [13] на английский язык.

Во время поездки Б. В. в Израиль он встретился со многими знакомыми, очень сердечно принявшими его. Поездку организовал львовский ученик Бориса Владимировича - Д. Г. Мейзлер, к тому времени долгие годы проживший в Израиле. Д. Г. Мейзлер умер в январе 1996 г., через несколько дней после того, как он узнал о смерти Бориса Владимировича.

Написанное - лишь малая часть того, что можно было бы написать.

\section{Б. В. Гнеденко как человек}

В этом разделе собраны отрывки воспоминаний Б. В., его высказывания, эпизоды из его жизни. Этот материал, в своей совокупности, надеюсь, дает представление о его характере, взглядах, остром уме, доброжелательности, находчивости и других замечательных качествах. Почти каждый отрывок снабжен заголовком: например, название параграфа из воспоминаний [5] с указанием страниц.

Школьная секция Математического общества. Семинар по программированному обучению. Из [5], с. 410. «Я вспоминаю, ито однажды, когда А.И. Кострикин был деканом, он созвал Совет отделения математики механико-математического факультета с одной единственной иелью - осудить деятельность Колмогорова. Сам он никогда вопросами математического образования не занимался и поэтому только огрублял формулировки Понтрягина. Я сидел рядом с Андреем Николаевичем и увидел, как голова его склоняется, и из глаз капают слезы. Я был возмущен выступлением декана и произнес лишь краткую, телеграфного стиля речь.

«Нельзя судить о вкладе Колмогорова, не вникая в смисл его предложений, а основная его идея, концепци, интересна и полезна. Она состоит в приближении школьного курса геометрии $к$ тому, ито от него требует современная физика. Нельзя перекладьвать на Колмогорова все недостатки школь. Школа - общественное явление, и она отражает в полной мере состояние нашего общества. Пройдет 
некоторое время, и мы вернемся $\kappa$ идее преобразования математического образования, высказанной Колмогоровым. Не торопитесь хоронить то, что заслуживает развития». K сожалению, мои слова не могли изменить общего впечатления от речи Кострикина. Мне же било тяжело думать о том, как много находится людей, способньх лягнуть льва, когда он немощен и беззащитен».

Август-сентябрь 1945 года. Из [5], с. 205-206. После того, как Б.В. с семьей получили квартиру от Львовского университета: «Mbl с Наташей решили, что нам нужно оборудовать гостевую комнату, поскольку придется устраивать моих будущих коллег на временное житье. Вместо того чтобь каждьй раз беспокоиться о гостиниче, проще было такую комнату оборудовать у нас. Мы поняли это своевременно».

Далее Б. В. перечисляет преподавателей университета, приглашенных для работы во Львове:

«Ко мне домой прямо с поезда явился И.Г. Соколов, с которым я встречался в Москве, первоклассньй университетский преподаватель, работавший ранее в Днепропетровском университете и в одном из втузов Москвьл.

Лопатинский приехал во Львов в коние года и остался. Волковысский перебрался во Львов только года через два.

Все трое, прежде чем поселиться на постоянньх квартирах, в среднем не меньше месяча жили у нас. Я свято соблюдал обещания, и мьг угошали наших гостей и жареньм гусем с картошкой, и жареньми телячьими ножками, и первоклассньм творогом, и молоком с рынка. Материальных трудностей в ту пору я уже не испьтыввал.

Со всеми мь сохранили самье теснье дружеские отношения на долгие годы. Так наша квартира стала иентром встреч новых львовян - математиков и механиков, и никто больше не претендовал на подобную роль. Наташа терпеливо сносила сваливииеся на нее заботы»》.

1948 год. Из [5], с. 232-233. Речь идет об избрании Б. В. в академики АН УССР. «М.Г.Крейн, математик мирового уровня, непрерьвно и активно работавший в бункциональном анализе и теории функиии, бъл практически всю жизнь связан с институтом математики АН УССР. Он был профессором ряда вузов, превосходным лектором. Последние годы Марк Григорьевич работал в Одессе.

Мне было не по себе от того, что я перебегал дорогу двум математикам (М.Г.Крейну и Н.И. Ахиезеру. - Авт.), заслуги которых я ставил выше своих. B результате размышлений и разговора с Наташей я решил написать личное письмо президенту Академии А. В. Палладину с просьбой избрать в первую очередь М. Г. Крейна.

Примерно через месяи после отправления письма я был пригла- 
шен $к$ А.В.Палладину и мне был сделан серьезный выговор за самовольство, за то, что я пьтаюсь делать политику, не учитьввя всех сторон дела. Письму ход дан не был. Со мной побеседовал также М. А. Лаврентьев. Он мне сказал, что прекрасно относится $\kappa$ М.Г.Крейну и у него неоднократно возникала идея об избрании Марка Григорьевича академиком, но ничего из этого не получилось. Он мне посоветовал больше не предпринимать дальнейших шагов по вьдвижению кандидатурь Крейна, поскольку это «мертвый номер», как он выразился. Мне бьло неприятно все это выслушивать, поскольку я видел, что совершается явная несправедливость.

Тридиатого июня на сессии Академии я получил лишь три голоса против и бьл избран академиком Украинской Академии наук».

Из слышанного от Б. В. Во время экзамена по теории вероятностей один студент заявил, что желает экзаменоваться на аварском языке. Б. В. не растерялся и написал ему вопрос в виде примера, который можно решить при помощи простейшей формулы, без единого слова. Студент показал полное незнание и получил неоспоримую «двойку».

Из слышанного от Б.В. К Б.В. однажды пришел академикфункционер. Окинув взглядом стены кабинета, он спросил: «Борис Владимирович, а почему у вас нигде нет портрета Сталина?» У самого этого деятеля значок со Сталиньм был на лаикане пиджака. Б. В. мгновенно нашел, что ответить: «Образ вождя нужно иметь не на стене, не на лачкане пиджака, а в сердие».

Свердловские будни. Из [5], с. 177. «Видел я Ипатьевский дом, но посещать его мне не хотелось - расстрел иарской семьи мне всегда казался делом кровавьл, лежащим страшньл пятном на совести деятелей Октябрьской революиии».

1948 год. Из [5], с. 236. «В начале зимыл я приехал в Москву. Как всегда, пришел в университет. Меня встретил Л. А. Тумаркин и говорит мне: «Как хорошо, что Выл, Борис Владимирович, приехали в Москву. Я попрошу Вас сделать у нас на факультете доклад насчет генетики с критикой антинаучных взглядов этой теории и, конечно, Вы коснетесь ошибок и наших коллег». - «Лев Абрамович, я не могу сделать такой доклад, так как совершенно не знаю генетики». В ответ я усльишал: «Борис Владимирович, вот и хорошо, что не знаете, - одновременно с подготовкой доклада Bъи познакомитесь и с генетикой». - «Дорогой Лев Абрамович! Что Выл мне предлагаете: я не знакомился с генетикой, когда она была наукой. Теперь же признано, ито это лженаука, и Вы предлагаете мне ее изучать. Нет, я не согласен». Лев Абрамович не нашел слов, чтобь мне ответить. Так мне удалось отделаться от предложения, которое било противно всем моим убеждениям, моей совести».

Л.А. Тумаркин - профессор МГУ, но, судя по этому и другим 
эпизодам, упоминаемым Б. В., был наделен какими-то общественными функциями.

Поступление в университет. Из [5], с. 34-35. «Экзамень шли один за другим. Пятерки были получены за математику устную, письменную работу по русскому языку, устный экзамен по литературе. $\mathrm{Ha}$ этом экзамене преподаватель меня спрашивает:

- Не ошиблись ли Bы, подав заявление на математический факультет? Вам бы нужно было поступать на филологический.

Я покорил его тем, что знал на память множество стихотворений Пушкина, Лермонтова, Кольцова, Некрасова и других русских поэтов. Без затруднений отвечал на предлагавшиеся мне вопросы. Я ответил, что литературу люблю, но учиться хочу на математическом факультете.

В эти дни к нашему дому пристал котенок, и мама его приютила. Каждый раз, когда я отправлялся на экзамен, я ему говорил: если сдам на пятерку, то куплю тебе 100 грамм мяса. Экзамены были сданы. Котенок получил столько кусков мяса, сколько бьло экзаменов».

Б. В. поступил в университет в 15 лет по особому разрешению наркома просвещения А. В. Луначарского.

Обстановка на механико-математическом факультете КГУ. Из [5], с. 259-261. «А в это время в университете подрастали способные математики - В.С. Михалевич и А.В.Скороход. У Скорохода был особенно яркий математический талант. Уже на первом курсе он написал работу, опубликованную в ДАН СССР. Но и эти молодые люди вызывали у факультетского начальства бурю протестов. По поводу каждого из них мне приходилось обращаться в ЦК и отстаивать их кандидатуры в аспирантуру

Помню заседание Ученого совета факультета, на котором рассматривалась кандидатура А.В. Скорохода в аспирантуру. С протестом против этой кандидатуры выступил секретарь парткома факультета Дмитренко. Он заявил, что таким, как Скороход, нет места в нашей аспирантуре, поскольку во время оккупачии он сотрудничал с Геббельсом. Я спросил: «Сколько лет было Скороходу, когда его завербовал Геббельс, и какие документальнье свидетельства имеются на этот счет?» Дмитренко пытался увильнуть от ответа, но я не давал ему и Совету перейти к другим вопросам. Когда же он не ответил на мой вопрос, я заявил: «Каждый легко подсчитает, ито А. В. Скороходу было 12 лет, когда на него 'обратил внимание' Геббельс, а когда мальчику исполнилось 13 лет - Никополь был освобожден Советской армией». Все ясно увидели клевету, возведенную на молодого человека в его отсутствие, когда он не мог защитить себя от навета. Совет рекомендовал его большинством голосов».

Мой разговор с Б. В. в 1964 г. Б.В. тепло относился к моему 
шефу по оборонному институту Н. П. Бусленко: «Он не боится умных людей», - говорил о нем. В 1964 г. партком поставил вопрос о моем вступлении в партию, и неожиданно Бусленко занял жесткую позицию: «Раз вы хотите работать в этом институте, вы должны сделать этот шаг». Конечно, я спросил совета у своего учителя Б.В. Вот что он мне ответил (помню почти дословно): «Если бы речь шла о вступлении в партию моих сыновей, я бы отнесся к этому вполне спокойно: молодежь не должна нести тот моральный груз, который испытывают старшие люди. Я же видел столько мерзостей, и все они делались именем партии! В Киеве мне предлагали и даже указали трех человек, готовых дать мне рекомендации, но я всегда решительно отказывался».

Начало эвакуации. Из [5], с. 145 . «Вскоре после моего возвращения с рытья окопов $к$ нам на два дня приехал мой школьный товарищ Шура Сперанский. Он вернулся с фронта из-под Ельни. Как техник-строитель, он был мобилизован в строительную часть, имел звание старшего лейтенанта. Он рассказывал нам об ужасах, творившихся под Ельней. Войска, которьли там командовал Г. К. Жуков, не только оборонялись, но и наступали. Потерь при этом не считали. Была поставлена задача - взять Ельню. Во что это нам обойдется, командование не думало. Немиь же хорошо укрепились, все подступь $\kappa$ их позичиям простреливались из дотов и дзотов пулеметныл и артиллерийским огнем. Ельня была взята, но все поле перед ней было покрыто телами наших солдат и офичеров. Враг не выдерживал психологически: когда перед глазами гибель сотен и тылсяч людей, то самыий черствый человек не выдерживает. Я живо представил себе эту картину и ужаснулся. С тех пор у меня Г. К. Жуков ассочиировался не столько с победами, сколько с человеческими потерями».

Как и его соратники А. Н. Колмогоров, П. С. Александров, А. Я. Хинчин, Борис Владимирович был всесторонне одаренным человеком, обладающим глубокими познаниями в истории (в первую очередь истории науки), литературе, архитектуре, свободно общался на основных европейских языках. Помню, он говорил, что математик должен любить не только красоту форм, но и красоту природы. Знал и любил классическую музыку. В какой бы стране он ни был, интересовался бытом, историей, культурой народа.

\section{СПИСОК ЛИТЕРАТУРЫ}

1. Гнєденко Б. В. Курс теорї ймовірностей. Львів, 1950.

2. Гнеденко Б. В. Курс теории вероятностей. Изд. 10-е, доп. M.: URSS, 2010.

3. Борис Владимирович Гнеденко в воспоминаниях учеников и соратников. М.: URSS, 2006, 190 c.

4. Марьянович Т. П. Быть благодарным судьбе (Слово об учителе). Донецьк: ІПШІ, «Наука і освіта», 2009. 
5. Гнеденко Б.В. Воспоминания: Моя жизнь в математике и математика в моей жизни. Под ред. Д. Б. Гнеденко. М.: Книжный дом «ЛИБРОКОМ», 2012, 620 с.

6. Гнеденко Б. В. К методике и технике установления потерь в производительности оборудования. - Бюлл. ИВНИТИ, 1934, № 3-4, с. 114-117.

7. Гнеденко Б. В. Вычисление среднего перехода между станками. - Бюлл. ИВНИТИ, 1934, № 1-2, с. 117-122; № 10-12, с. 118-122.

8. Гнеденко Б. В. О среднем простое станков при многостаночном обслуживании. Изв. хлопчато-бумажн. промышл., 1934, № 11, с. 15-18.

9. Гнеденко Б.В., Колмогоров А.Н. Предельные распределения для сумм независимых случайных величин. М.-Л.: Гостехиздат, 1949, 264 с.

10. Франкен П., Кёниг Д., Арндт У., Шмидт Ф. Очереди и точечные процессы. Киев: Наукова думка, 1984, 283 с.

11. Гнеденко Б. В., Королюк В. С., Ющенко Е. Л. Элементы программирования. М.: Физматгиз, 1961.

12. Гнеденко Б. В. Лекции по теории массового обслуживания. Вып. 1, 2. Киев: КВИРТУ, 1959, 1960.

13. Гнеденко Б. В., Коваленко И. Н. Лекции по теории массового обслуживания. Вып. 3. Киев: КВИРТУ, 1963.

14. Гнеденко Б. В. О ненагруженном дублировании. - Изв. АН СССР. Сер. Техн. киберн., 1964, № 4, с. 3-12.

15. Гнеденко Б. В. О дублировании с восстановлением. - Изв. АН СССР. Сер. Техн. киберн., 1964, № 5, с. 111-118.

16. Гнеденко Б.В., Беляев Ю.К., Соловьев А.Д. Математические методы в теории надежности: Основные характеристики надежности и их статистический анализ. М.: Наука, 1965, 524 с.

17. Gnedenko B.V., Korolev V.Y. Random Summation: Limit Theorems and Applications. Boca Raton: CRC Press, 1996, 267 p.

18. Гнеденко Б. В., Коваленко И. Н. Введение в теорию массового обслуживания. М.: Наука, 1966, 431 с.; последнее изд.: M.: URSS, 2011.

19. Gnedenko B. V., König D. (Eds.). Handbuch der Bedienungstheorie, v. I, II. Berlin: Akademie-Verlag, 1983, 1984, 520 p., 607 p.

20. Королюк В. С., Гнеденко Д. Б., Демидов С. С. Страница жизни Бориса Владимировича Гнеденко - историографа математики. - Историко-матем. иссл., сер. 2, 2005, № 10(45), c. 126-142.

21. Гнеденко Б.В., Рыбников К.А., Симонов Н. И. Проблемы истории математики Нового времени. - Историко-матем. иссл., 1963, № 15, с. 73-96.

22. Александров П.С., Гнеденко Б. В., Степанов В.В. Математика в Московском университете в ХХ веке (до 1940 г.). — Историко-матем. иссл., 1948, № 1, с. 942.

23. Гнеденко Б.В. Михаил Васильевич Остроградский: Очерки жизни, научного творчества и педагогической деятельности. М.: Гостехиздат, 1952, 331 с.

24. Гнеденко Б. В., Погребысский И. Б. Михаил Васильевич Остроградский. 18011862: Жизнь и работа. Научное и педагогическое наследие. М.: АН СССР, 1963, $271 \mathrm{c}$.

25. Гнеденко Б. В., Погребисский И. Б., Штокало И. З., Юшкевич А. П. О проблемах истории математики в России и в СССР и о работах в этой области за 19561961 гг. - Историко-матем. иссл., 1963, № 15, с. 11-36.

Поступила в редакцию 21.XII.2012 